\title{
PENGEMBANGAN MODUL ELEKTRONIK BERBASIS 3D PAGEFLIP PROFESSIONAL MATA KULIAH GAMBAR TEKNIK DI PROGRAM STUDI PENDIDIKAN TEKNIK MESIN
}

\author{
Nopriyanti \\ Universitas Sriwijaya \\ Email: nopriyanti@fkip.unsri.ac.id
}

\begin{abstract}
This study aims to: (1) develop an electronic module based on 3D Pageflip Professional for Engineering Drawings course, (2) assess the quality of the electronic modules. The model the research is research and development $(R \& D)$. The electronic module was validated by learning media experts and learning material experts. The research subject was the 32 students of mechanical engineering education study program of FKIP UNSRI. The study concludes that: (1) the electronic module that is based on 3D Pageflip Professional for Engineering Drawing Course is appropriate to use for learning process; (2) the quality of the product is very good. The assessment from the experts resulted in a score of 85 for the display aspect (very good), 51 for the learning process aspect (good), and 54 for the learning material aspect. Whereas, from the students, it is 956 (very good) for the display aspect, 684 for the learning process aspect, and 847 for the content aspect (very good).
\end{abstract}

Keywords: electronic modules, 3D pageflip professional, engineering drawing course

\begin{abstract}
ABSTRAK
Penelitian ini bertujuan untuk: (1) menghasilkan Modul Elektronik Berbasis 3D Pageflip Professional pada mata kuliah Gambar Teknik, (2) mengetahui kualitas Modul Elektronik Berbasis 3D Pageflip Professional pada mata kuliah Gambar Teknik. Penelitian ini merupakan penelitian dan pengembangan (R\&D). Validasi modul elektronik ini dilakukan oleh ahli media dan ahli materi. Subjek uji coba penelitian ini adalah 32 mahasiswa program studi pendidikan teknik mesin FKIP UNSRI. Hasil penelitian ini adalah: (1) produk modul Elektronik Berbasis 3D Pageflip Professional pada mata kuliah Gambar Teknik layak untuk digunakan; (2) Kualitas produk modul elektronik ini sangat baik, hasil penilaian ahli media dan ahli materi ditinjau dari aspek tampilan 85 (sangat baik), aspek pembelajaran 51 (baik), dan aspek materi 54 (baik). Sedangkan hasil penialaian peserta didik uji coba lapangan pada aspek tampilan sebesar 956 (sangat baik), pada aspek pembelajaran sebesar 684 (sangat baik), dan pada aspek isi sebesar 847 (sangat baik).
\end{abstract}

Kata kunci: modul elektronik, gambar teknik, Pageflip Professional

\section{PENDAHULUAN}

Keberhasilan dalam menciptakan lulusan yang kompeten dan memiliki kemampuan yang tinggi tidak luput dari peran dosen dan fasilitas yang ada pada proses pembelajaran di sekolah. Proses pembelajaran memegang peranan penting dalam menghasilkan lulusan yang kompeten dan profesional. Proses pembelajaran yang berkualitas akan menghasilkan output yang berkualitas juga dan sebaliknya, jika proses pembelajarann yang dilaksanakan tidak sesuai dengan kriteria maka lulusannya pun akan berbeda. Faktor penentu keberhasilan dalam proses pembelajaran tersebut diantaranya adalah kompetensi pedagogik dosen dan penggunaan media. Dosen yang aktif dan mempunyai kreatifitas dalam melaksanakan pembelajaran masih sangat minim ditemukan. Keterbatasan media atau keinginan dosen dalam menggunakan media itu sendiri masih minim sehingga pelaksanaan pembelajaran yang dilakukan kurang optimal. Selain itu, keterbatasan dosen dalam memanfaatkan dan mengembangkan teknologi dan komunikasi yang berkembang saat ini masih kurang.

Berdasarkan pengamatan selama kegiatan pembelajaran matakuliah Gambar Teknik diperoleh hasil antara lain: (1) rendahnya 
kualiatas belajar mahasiswa mata kuliah Gambar teknik; (2) sebagian besar mahasiswa masih kesulitan memahami materi yang disampaikan; (3) cara penyampaiaan materi yang dilakukan dalam proses pembelajaran ini masih berorientasi pada pendekatan pembelajaran yang berpusat pada dosen (lecture centered); (4) cara penyampaiaan materi yang dilakukan oleh dosen dalam proses pembelajaran ini masih terlalu monoton; (4) mahasiswa kebanyakan bosan dan tidak memperhatikan dosennya; (5) kurangnya bahan ajar yang akan digunakan dalam pembelajaran ini; (6) kurangnya sumber belajar pada mata kuliah Gambar Teknik ini; (7) Hasil belajar mahasiswa masih tergolong rendah; (8) Aktivitas mahasiswa dalam kegiatan pembelajaran ini hanya duduk, mendengarkan penjelasan, mencatat dan menghapal materi yang diberikan sehingga membuat mahasiswa kebanyakan bosan dan tidak memperhatikan.

Upaya perbaikan yang dilakukan agar kegiatan belajar mengajar dapat berlangsung dengan baik dan optimal adalah dengan cara meningkatkan kualitas pembelajaran. Kualitas pembelajaran dapat ditingkatkan dengan cara mengubah strategi pembelajaran yang dilakukan dosen. Dosen merupakan aktor utama dalam proses pembelajaran. Dosen harus memiliki strategi pembelajaran yang kuat dan sesuai sehingga dapat mendukung proses pembelajaran di dalam maupun di luar kelas. Dosen juga merupakan salah satu faktor kunci yang ikut menentukan arah pembelajaran dan keberhasilan mahasiswa dalam proses pembelajaran. Hal yang dapat dilakukan untuk mengimbangi proses pembelajaran adalah dengan cara meningkatkan mutu dan kualitas pembelajaran. Pemanfaatan teknologi bisa menjadi salah satu cara untuk memperbaiki proses pembelajaran tersebut.

Pemanfaatan Gambar Teknik dalam pembelajaran merupakan hal yang penting untuk mencapai tujuan intruksional yang telah disusun. Gambar Teknik adalah alat, metoda dan teknik yang digunakan dalam rangka lebih mengefektifkan komunikasi dan interaksi antara pengajar dan mahasiswa dalam proses pendidikan dan pengajaran di sekolah. Gambar
Teknik juga merupakan unsur yang paling penting dalam proses pembelajaran. Gambar Teknik merupakan alat atau bahan yang digunakan dalam proses pembelajaran yang mengandung informasi dan pesan pembelajaran. (Hamalik, 2009, p.12),

Berdasarkan permasalahan di atas, untuk menyiapkan dan menghasilkan lulusan yang berkompeten pada matakuliah Gambar Teknik ini dibutuhkan proses pembelajaran yang baik dan bermutu. Proses pembelajaran yang baik dan bermutu akan tercapai dengan melibatkan pendidik yang kompeten, alat, media, dan sarana prasarana yang lainnya. Permasalahan yang dihadapi oleh mahasiswa dan dosen dalam proses pembelajaran membutuhkan pemecahan masalah agar kegiatan pembelajaran dapat berjalan secara efektif dan efisien. Hal ini diperlukan Pengembangan Modul Elektronik Berbasis 3D Pageflip Professional pada Mata Kuliah Gambar Teknik di Program Studi Pendidikan Teknik Mesin FKIP UNSRI”.

Penelitian ini bertujuan untuk: (1) Menghasilkan Modul Elektronik Berbasis 3D Pageflip Professional Pada Mata Kuliah Gambar Teknik di Program Studi Pendidikan Teknik Mesin FKIP Unsri; (2) Mengetahui kualitas Modul Elektronik Berbasis 3D Pageflip Professional Pada Mata Kuliah Gambar Teknik di Program Studi Pendidikan Teknik Mesin FKIP Unsri

\section{METODE}

Prosedur pengembangan materi ajar ini mengacu kepada model disain instruksional 4D yang diperkenalkan oleh Thiagarajan (1974). Sedangkan untuk mengontrol kualitas materi ajar yang dikembangkan digunakan prosedur evaluasi formatif yang diintegrasikan dalam tahap develop. Adapun prosedurnya dapat dilihat pada Gambar 1. 


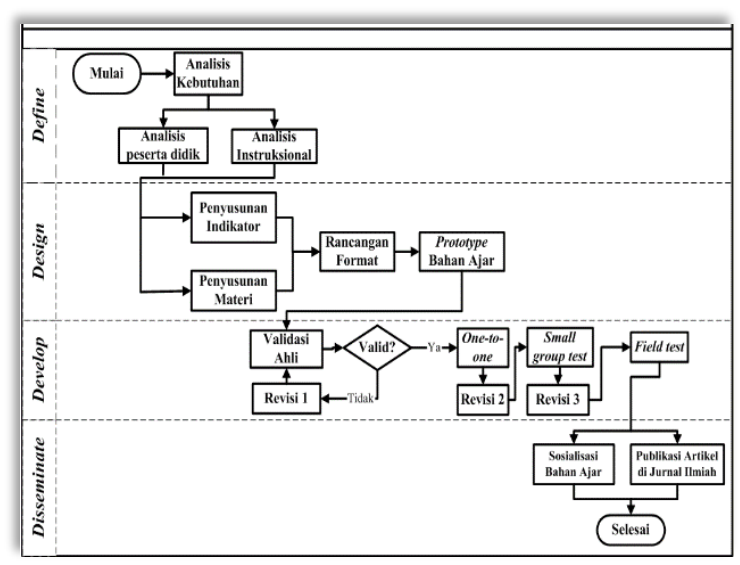

Gambar 1. Prosedur Pengembangan 4D

Berdasarkan skema pada Gambar 1, prosedur pengembangan dibagi atas empat tahapan, yaitu: define, design, develop, dan disseminate. Masing-masing tahapan tersebut memiliki kegiatan sebagai berikut: (1) Define. Tahap ini terdiri atas tiga kegiatan, yaitu: (a) Analisis kebutuhan : Pada tahap ini dilakukan analisa kebutuhan melalui identifikasi terhadap permasalahan dan studi literatur; (b) Analisis peserta didik: Tahap ini dilakukan identifikasi terhadap peserta matakuliah Gambar teknik; (c) Analisis instruksional. Pada tahap ini disusun tujuan instruksional untuk matakuliah Gambar teknik, serta dipilih dan dirancang urutan materi ajar. (2) Design. Kegiatan utama pada tahap ini terdiri dari empat kegiatan, yaitu: penyusunan tes, penyajian materi, penentuan format, dan rancangan prototype materi ajar. (3) Develop. Kegiatan pada tahap ini terdiri dari tujuh kegiatan: (a) Validasi ahli. (b) Revisi 1. (c) Evaluasi One-to-one. (d) Revisi 2. (e) Small group test. (f) Revisi 3. (g) Field test; (4) Dissemination. Kegiatan pada tahap ini terdiri dari dua, yaitu: (a) Sosialisasi materi ajar. Sosialisasi ini dilakukan melalui implementasi pembelajaran matakuliah Gambar Teknik dengan memanfaatkan web e-learning Unsri. (b) Publikasi. Hasil pengembangan ini akan dipublikasikan dalam bentuk artikel ilmiah yang akan dimasukkan ke dalam jurnal ilmiah nasional yang terakreditasi.

Uji Coba merupakan bagian terpenting dalam penelitian pengembangan. Uji coba menghasilkan temuan tentang kelemahan, kekurangan, kesalahan produk dan saran-saran. Tujuan uji coba ini adalah untuk mengetahui kualitas dari produk media yang dikembangkan dan apakah Modul Elektronik ini layak atau tidak untuk digunakan. Subjek validasi produk adalah 2 orang ahli yaitu ahli materi dan ahli media, sedangkan subjek uji coba produk Modul Elektronik dalam penelitian pengembangan ini adalah mahasiswa. Pengambilan data dibagi sebanyak tiga kali dengan mahasiswa yang berbeda.

Jenis instrumen yang digunakan dalam penelitian ini sebagai berikut: Instrumen angket berupa lembar penilaian dalam bentuk lembar validasi berisi butir-butir penilaian untuk setiap aspek, baik aspek pembelajaran, aspek isi/materi, aspek tampilan yang akan diisi oleh ahli media, ahli materi, dan subjek uji coba. Validasi instrumen dalam penelitian ini merupakan validasi instrumen angket yang akan digunakan untuk menilai produk modul elektronik ini yang dikembangkan. Instrument yang divalidasi berupa instrumen angket untuk ahli media, ahli materi dan siswa sebagai pengguna. Instrument angket ini terdiri dari 3 aspek penilaian, yaitu: aspek tampilan, aspek pembelajaran dan aspek isi.

Seluruh instrumen tersebut diberikan kepada seorang dosen ahli yang ditunjuk sebagai validator untuk memvalidasi instrumen, kemudian hasil dari validasi tersebut dianalisis dan dilakukan perbaikan jika terdapat kesalahan dalam penyusunan instrumen. Setelah instrumen tersebut dinyatakan valid oleh validator selanjutnya instrumen dapat digunakan untuk melakukan penelitian.

Produk modul elektronik yang telah dikembangkan selanjutnya akan dinilai dan divalidasi oleh validator ahli. Kriteria penilaian produk modul elektronik ini tertuang dalam instrumen angket yang telah divalidasi sebelumnya.

Data yang diperoleh dari hasil penilaan ahli materi, ahli media, dan subjek uji coba (mahasiswa) dianalisis dengan menggunakna kategori kecenderungan data. Penilaian dilakukan untuk mendapatkan tanggapan 
tentang kualitas produk yang dikembangkan. Hasil berupa skor dari penilaian tersebut kemudian dikonversikan menjadi nilai, setelah itu dengan menggunakan tabel kecenderungan data untuk menentukan kategori penilaian. Kecenderungan data berdasarkan acuan Sukarjo (2008) disampaikan dalam Tabel 1.

Tabel 1. Kategori kecenderungan data

\begin{tabular}{cc}
\hline Interval & Kategori \\
\hline$\left(\bar{X}_{i}+1,80 \mathrm{Sbi}\right)<\mathrm{X}$ & Sangat Baik \\
$\left(\bar{X}_{i}+0,60 \mathrm{Sbi}\right)<\mathrm{X} \leq\left(\bar{X}_{i}+1,80 \mathrm{Sbi}\right)$ & Baik \\
$\left(\bar{X}_{i}-0,60 \mathrm{Sbi}\right)<\mathrm{X} \leq\left(\bar{X}_{i}+0,60 \mathrm{Sbi}\right)$ & Cukup \\
$\left(\bar{X}_{i}-1,80 \mathrm{Sbi}\right)<\mathrm{X} \leq\left(\bar{X}_{i}-0,60 \mathrm{Sbi}\right)$ & Kurang \\
$\mathrm{X} \leq\left(\bar{X}_{i}-1,80 \mathrm{Sbi}\right)$ & Sangat Kurang \\
\hline
\end{tabular}

Keterangan:

$\bar{X} \mathrm{i} \quad=1 / 2($ maksimal + skor minimal $)$

$\mathrm{SBi}=1 / 6$ (skor maksimal - skor minimal)

$\mathrm{X}=$ Skor aktual

Rata-rata penilaian menggunakan rumus berikut:

$$
\bar{X}=\frac{\sum X}{n} \text { (Irianto, 2008, p.29) }
$$

Keterangan:

$$
\begin{aligned}
& \bar{X}=\text { Rata-rata } \\
& X=\text { Hasil skor (pretes / postes) siswa } \\
& n=\text { Jumlah siswa }
\end{aligned}
$$

\section{HASIL DAN PEMBAHASAN}

Sebagaimana prosedur penelitian yang telah dikemukakan sebelumnya, pengembangan ini terdiri dari 4 langkah utama, yaitu: define, design, develop, dan disseminate.

Define. Pengembangan modul elektornik Gambar Teknik ini diawali dengan melakukan studi pendahuluan yaitu mencari/menganalisis hal-hal yang mendukung pengembangan modul elektronik ini. Adapun data yang diperoleh dari studi pendahuluan ini sebagai berikut:

Analisis kebutuhan pengembangan dilakukan untuk mendapatkan informasi tentang sejauh mana pengembangan modul elektronik ini dibutuhkan dalam mengoptimalkan pelaksanaan proses dan hasil belajar Gambar Teknik maupun mata pelajaran lain yang terkait. Data pada langkah pertama diambil dari hasil observasi dan hasil wawancara dengan dengan beberapa mahasiswa yang mengikuti mata kuliah tersebut. Data hasil langkah pertama ini berupa kebutuhan lapangan akan Gambar teknik. Peserta berpendapat bahwa mereka belum banyak mendapatkan pengalaman belajar yang lebih bervariasi.

Analisis peserta didik ini dilakukan untuk melihat kondisi mahasiswa secara langsung (observasi). Analisis ini dilakukan dengan observasi dan wawancara dengan mahasiswa. Hasil dari analisis peserta didik yang dilakukan diperoleh kesimpulan bahwa Dosen dan Mahasiswa kesulitan mendapatkan sumber belajar yang lengkap dalam satu paket. Pendidik dan mahasiswa membutuhkan salah satu media yang dapat menunjang proses pembelajaran.

Dengan adanya pengembangan modul ini diharapkan dapat mengatasi beberapa masalah yang dihadapi oleh pendidik maupun peserta didik sehingga mahasiswa bisa menerima materi dengan baik. Selain itu, dengan pengembangan modul elektronik ini diharapkan mahasiswa mampu mengembangkan diri dalam hal pembuatan Gambar Teknik baik ketika materi ini diberikan dan ketika praktek pengalaman lapangan (PPL) berlangsung hingga pada saat mereka benar-benar mengajar di salah satu sekolah.

Fokus pencapaian dari pembelajaran ini diharapkan mahasiswa sebagai sasaran pengguna produk ini mempunyai hasil belajar dan penguasaan materi yang baik setelah menggunakan modul elektronik ini. Pengembangan modul elektronik ini dikembangkan berdasarkan silabus/RPS dan tujuan instruksional yang terdapat dalam RPS setiap program studi.

Design. Kegiatan utama pada tahap ini terdiri dari empat kegiatan, yaitu: penyusunan tes, penyajian materi, penentuan format, dan rancangan prototype materi ajar.

Menyusun naskah dan mengumpulkan materi yang akan digunakan dalam pengembangan Gambar teknik. Materi yang dikumpulkan terlebih dahulu di susun dan dibuat dalam bentuk word. Penyusunan naskah/materi Gambar Teknik ini harus berdasarkan 
kompetensi yang ada sehingga tujuan-tujuan yang terdapat dalam silabus tersebut dapat terlaksana dan terpenuhi dan artinya modul elektronik media pemeblajaran ini bisa digunakan berkali-kali dalam setiap pembelajaran setia tahunnnya.

Membuat flowchart (bagan alur) dan storyboard yang akan digunakan sebagai pedoman dalam pengembangan media ini. Flowchart merupakan diagram alur dalam pembuatan modul elektronik ini. Sedangkan langkah selanjutnya adalah pembuatan storyboard. Storyboard digunakan untuk menggambarkan bentuk setiap tampilan dalam setiap frame dalam modul yang dikembangkan. Flowchart dan Storyboard yang dibuat untuk membantu pengembang dalam mengembangkan modul Gambar Teknik ini, sehingga materimateri dan kegiatan tidak melenceng sesuai yang dengan Rencana Pembelajaran Semester (RPS).

Menentukan software yang akan digunakan menetukan software-software apa saja yang akan digunakan dalam pengembanagn Gambar teknik. Software yang digunakan dalam pengembangan ini adalah 3D PageFlip Professional 1.6.8.

Penyajian materi. Kegiatan ini bertujuan untuk memilih dan menyusun materi yang akan disajikan pada bahan ajar. Hal ini akan disesuaikan dengan format bahan ajar yang akan ditentukan. Materi yang disusun diambil dari beberapa buku cetak dan buku elektronik yang berkaitan dengan Gambar teknik. Materi-materi dari buku tersebut diambil dan disusun terlebih dahulu dalam bentuk word. Setelah itu diconvert ke dalam bentuk pdf. Selain itu, pengembang juga mencari 3D Pageflip Professional dan video yang akan digunakan dalam pengembangan ini.

Tes secara modular digunakan untuk memastikan awal pembuatan modul ini sesuai dengan flowchart dan storyboard. Tes secara modular ini juga dilakukan untuk mengetahui jalannya program secara keseluruhan dan pengetesan ke beberapa komputer dan android yang menggunakan Windows yang berbeda namun memiliki spesifikasi yang setara.
Selain melakukan tes/uji coba modul elektronik yang dikembangkan, pengembang juga menyusun tes kemampuan untuk melihat kemampuan mahasiswa setelah menggunakan modul elektronik Gambar Teknik ini. Kegiatan ini dilakukan penentuan indikator keberhasilan mahasiswa berdasarkan tujuan instruksional yang telah dirumuskan sebelumnya.

Development. Pengembangan modul elektronik ini secara keseluruhan membahas tentang materi Gambar teknik. Proses produksi media ini juga didasarkan pada rancangan prototype, flowchart, dan storyboard yang sudah dibuat sebelumnya serta bahan-bahan pendukung pembuatan produk yang lainya. Target pengguna produk modul elektronik berbasis 3D Pageflip Professional ini adalah mahasiswa yang sedang mengampuh mata kuliah Gambar teknika kelas Indralaya dan kelas Palembang. Modul ini dikemas dalam dua bentuk penyimpanan yaitu dalam bentuk Compact Disc (CD) dan Flashdisc. Semua bahan yang telah disiapkan pada tahap sebelumnya disatukan untuk membuat modul pembelajaran. Adapun tahaptahap pengembangan modul elektronik berbasis 3D Pageflip Professional ini antara lain sebagai berikut:

Mengembangkan naskah dan materi: materi yang telah disusun dan di kumpulkan sebelumnya digabungkan dan di convert menjadi pdf setelah itu di cover ke dalam bentuk modul elektronik berbasis 3D Pageflip Professional.

Mengedit gambar, video dan komponen yang lainnya selanjutnya di input ke software modul yang digunakan untuk pengembangan. Gambar, Suara, Video dan 3D Pageflip Professional yang telah di edit disusun dan digabungkan menjadi satu kesatuan.

Membuat produk dan merakit elemenelemen media: menggabungkan semua elemenelemen yang telah disusun sebelumnya sehingga terbentuk modul elektronik Gambar Teknik berbasis 3D Pageflip Professional. Produk awal yang telah selesai dikembangkan terlebih dahulu dilakukan pengecekan sebelum produk awal divalidasi dan diuji cobakan kepada peserta 
didik. Pengecekan dilakukan secara internal yaitu dimulai dengan pengecekan jalannya program secara keseluruhan. Secara garis besar produk modul elektronik hasil pengembangan pada tahap awal ini berisi:

Validasi ahli. Prototype bahan ajar yang telah dihasilkan pada langkah sebelumnya selanjutnya dilakukan evaluasi. Pengembang melakukan kegiatan di antaranya adalah; (1) evaluasi on going yaitu melakukan pengencekan terhadap komponen modul elektronik secara keseluruhan sehingga modul dinyatakan fiks sesuai dengan kebutuhan setelah itu meminta pembimbing untuk mengecek modul yang dikembangkan; (2) validasi produk awal yang dilakukan oleh dua orang ahli media dan dua orang ahli materi. Kriteria ahli media adalah seseorang yang memiliki pengalaman atau latar belakang pendidikan dibidang pengembangan bahan ajar. Sedangkan kriteria dari ahli materi adalah seseorang yang memiliki pengalaman dan latar belakang pendidikan yang berkaitan dengan bidang gambar teknik, terutama gambar teknik untuk pendidikan teknik mesin.

Revisi 1. Berdasarkan hasil konsultasi di atas dilakukan perbaikan terhadap prototype. Kegiatan ini berulang, hingga materi ajar dinyatakan valid dan dapat dilanjutkan. Pada pengembangan ini pengembang melakukan walidasi terhadap ahli media dan ahli matrei sebanyak 2 kali. Pada validasi pertama pengembang memperlihatkan modul yang dikembangkan dan validator menilai modul tersebut. Validator materi menilai modul tersebut dari segi materinya, bagaimana kelengkapan materi, bagaimana kejelasan materi, kesesuaian dengan kurikulum hingga ururtan penyajian materi pada modul ini. Sedangkan pada validator media yang dinilai adalah bagaima aspek tampilan dalam modul tersebut, penggunaan warna hingga pada gambar, gambar latar bagaimana hingga pada kemenarikan modul. Setelah penilaian selesai saran perbaikan yang diutarakan oleh validator ahli media dan materi tersebut diperbaiki. Setelah itu pengembang membawa kembali hasil perbaikan tersebut untuk ditunjukan kepada validator untuk dievaluasi kembali. Setelah dirasa modul sudah baik, pengembang meminta ahli untuk mengisi angket yang telah disediakan.

Evaluasi One-to-one. Langkah selanjutnya adalah menguji kepraktisan bahan ajar dengan meminta pendapat dari calon pengguna yang dalam hal ini adalah mahasiswa. Pada kegiatan ini bahan ajar diuji coba pada tiga orang mahasiswa yang mewakili calon pengguna. Pemilihan ketiga orang tersebut berdasarkan kriteria dengan kemampuan tinggi, sedang, dan rendah. Pada taham ini mahasiswa diberi angket berupa lembar penilaian untuk menilai modul tersebut, dan setelah itu mereka melakukan ujicoba penggunaan produk tersebut dan menilainya. Mahasiswa menggunakan modul ini dari kegiatan awal sampai akhir. Penilaian pada ujicoba ini terdiri dari aspek materi dan aspek media.

Revisi 2. Berdasarkan hasil evaluasi oneto-one dilakukan perbaikan terhadap bahan ajar. Revisi dilakukan untuk memperbaiki hal-hal yang disarankan oleh mahasiswa. Setelah perbaikan selesai ujicoba langsung diteruskan keuji cobal kelompok kecil (Small group test).

Small group test. Kegiatan selanjutnya adalah melakukan uji coba kepraktisan bahan ajar untuk digunakan pada kelompok terbatas, yakni berjumlah 10-12 orang. Dalam kegiatan ini umpan balik diperoleh melalui angket dan observasi. Dalam uji coba ini sama halnya dengak ujicoba satu-satu pada sebelumnya. Mahasiswa diminta unruk menggunakan modul ini dan memberikan penilaian terhadap modul yang telah dibuat.

Revisi 3. Dari hasil analisa terhadap umpan balik, kembali dilakukan perbaikan terhadap rancangan bahan ajar, sehingga diperoleh materi ajar yang praktis untuk digunakan oleh mahasiswa. Setelah perbaikan modul dilakukan pengembang melanjutkan ujicoba pada tahap akhir yaitu ujicoba kelompok besar (Field test).

Field test. Pada kegiatan ini bahan ajar kembali diujicobakan pada kelompok pengguna yang lebih banyak. Ujicoba dilakukan pada kurang lebih 30 mahasiswa. Penilaian dari 
kelompok ini berupa angket dan hasil test akhir. Angket digunakan untuk melihat kepraktisan dalam menggunakan modul ini. Penialian dalam bentuk ini juga digunakan untuk melihat kesempurnaan dari modul dari banyak mahasiswa.

Dessimination. Kegiatan pada tahap dessimination ini terdiri dari dua, yaitu: (a) Pembagian materi kepada mahasiswa yang mengampuh mata kuliah Gambar teknik, sehingga mereka mempunyai bahan ajar dan diharapkan dapat menjadi sumber utama dalam pembelajaran dan dapat mempermudah kegiatan pembelajaran yang mereka hadapi.

Validasi Produk Modul Elektronik. Data ini diperoleh dengan cara memberikan angket yang mencakup aspek tampilan. Validasi ahli media dilakukan oleh bapak H. Imam Syofii, S.Pd., M.Eng. Beliau merupakan dosen Program studi Pendidikan Teknik Mesin dan juga sekaligus sebagai Dosen yang pernah mengampu matakuliah Gambar Teknik dan ahli dibidang Gambar teknik. Penilaian yang dilakukan dalam bentuk instrumen angket yang telah disiapkan oleh pengembang.

Adapun hasil dari validasi oleh ahli media tersebut sebagai berikut: (a) Aspek Tampilan ini dimaksudkan untuk mengetahui bagaimana penilaian ahli media mengenai modul elektronik yang sedang dikembangkan. Penilaian ahli media berupa berbagai macam hal yang menyangkut aspek tampilan dari produk modul elektronik ini. Penilaian dalam aspek tampilan ini terdiri dari beberapa unsur yaitu: kualitas grafis, kualitas latar, kualitas huruf, kualitas musik, kualitas gambar dan kualitas 3D Pageflip Professional. Dengan pedoman penilaian ini, pengembang akan mengetahui perlu atau tidaknya revisi tahap pertama pada aspek ini.

Data yang diperoleh dari penilaian ahli media menunjukan bahwa: (a) kualitas grafis adalah "Baik" dengan rata-rata nilai “4”; (b) kualitas latar adalah "baik" dengan rata-rata nilai "4"; (c) kualitas huruf dari penilaian media adalah "sangat baik" dengan rata-rata nilai " 5 "; (d) kualitas gambar hasil yang diperoleh adalah “sangat baik” dengan rata-rata nilai “4,67”; (e) kualitas animasi hasil yang diperoleh adalah “baik” dengan rata-rata nilai “4”. Secara Visual, penilaian ahli media pada aspek tampilan tampak pada Gambar 2.

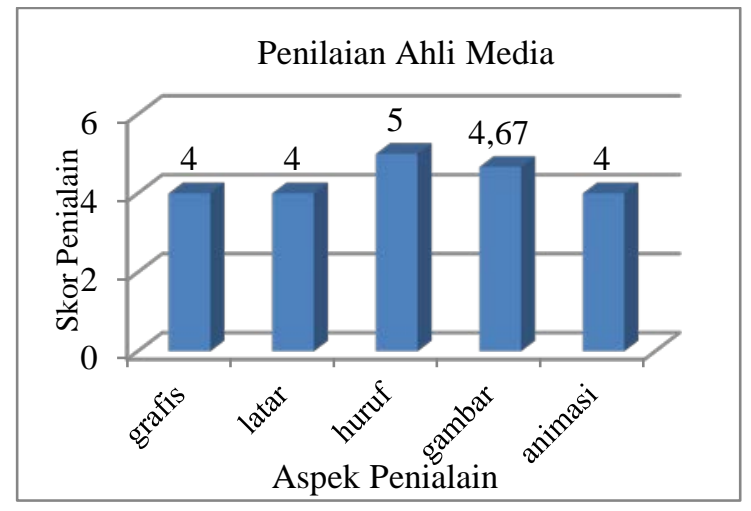

Gambar 2. Diagram hasil penilaian ahli media aspek tampilan

Dari hasil penilaian ahli media pada aspek tampilan, dapat disimpulakan bahwa modul elektronik yang dikembangkan mempunyai penilaian yang "Sangat Baik".

Data validasi ahli materi dalam penelitian ini diperoleh dengan cara memberikan instrumen validasi berupa angket penilaian yang mencakup aspek pembelajaran dan aspek isi. Validasi ahli materi ini dilakukan oleh ibu Dewi Puspita Sari, M.Pd. Beliau merupakan dosen Program studi pendidikan teknik mesin dan juga sekaligus sebagai Dosen yang pernah mengampu matakuliah Gambar teknik.

Adapun hasil dari validasi oleh ahli materi tersebut sebagai berikut: (a) Aspek pembelajaran ini dimaksudkan untuk mengetahui bagaimana tanggapan dan penilaian ahli materi mengenai kualitas kompetensi, kualitas pendahuluan, kualitas pembelajaran, dan kualitas evaluasi yang terdapat dalam modul elektronik ini. Data yang diperoleh dari penilaian ahli materi dari beberapa aspek pembelajaran menunjukan bahwa: (a) kualitas kompetensi bernilai "baik" dengan rata-rata " 4 "; (b) kualitas pembelajaran "baik” dengan rata-rata nilai “3,75"; (c) kualitas evaluasi “baik” dengan rata-rata nilai “4”. Secara Visual, penilaian ahli materi pada aspek pembelajaran tampak pada Gambar 3. 


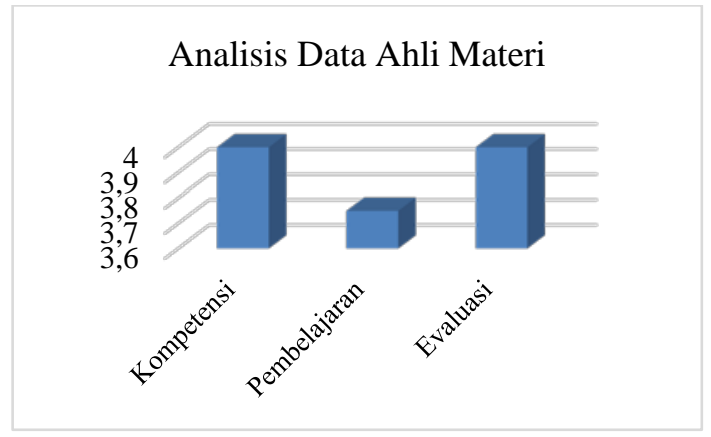

Gambar 3. Diagram perolehan skor aspek pembelajaran

Dari hasil penilaian ahli materi pada aspek pembelajaran dapat disimpulakan bahwa modul elektronik yang dikembangkan mempunyai penilaian yang "Baik”.

Aspek isi dimaksudkan untuk mengetahui bagaimana tanggapan ahli materi mengenai berbagai macam hal yang menyangkut isi dari produk modul elektronik ini. Dengan pedoman penilaian ini, pengembang akan mengetahui hasil penilaian oleh ahli materi dan mengetahui perlu tidaknya revisi tahap pertama pada aspek isi.

Data yang diperoleh dari penilaian ahli materi menunjukan bahwa: (a) kualitas materi bernilai "baik" dengan rata-rata "4"; (b) kualitas bahasa "baik" dengan rata-rata nilai "4"; (c) kualitas ilustrasi "cukup" dengan rata-rata nilai "3"; (d) kualitas tes "baik" dengan ratarata nilai “4”. Secara visual, penilaian ahli materi pada aspek isi/materi terlihat pada Gambar 4.

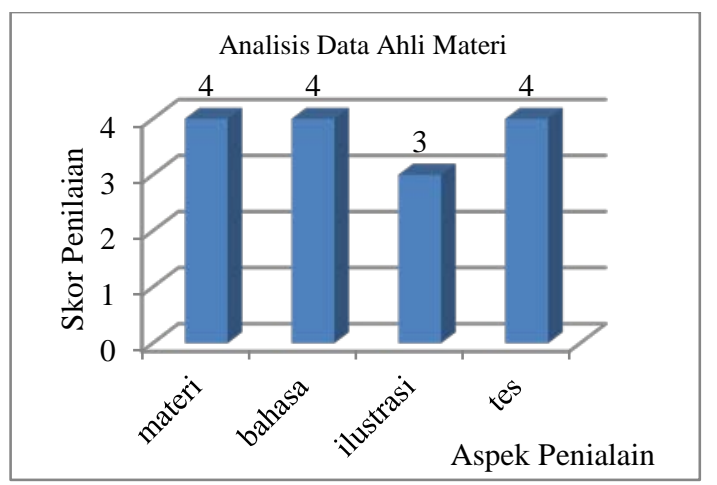

Gambar 4. Diagram perolehan skor aspek isi/materi
Dari hasil penilaian ahli materi pada aspek materi/isi, dapat disimpulakan bahwa modul elektronik yang dikembangkan mempunyai penilaian yang "Baik”.

Uji Coba Produk Modul Elektronik. Data ini diperoleh dengan cara memberikan angket kepada mahasiswa yang mencakup aspek tampilan, aspek pembelajaran dan aspek materi/isi. Uji coba satu-satu ini dilakukan kepada 3 orang mahasiswa, mereka diminta untuk menjadi subjek dalam uji coba satu-satu ini. Mahasiswa diminta untuk menggunakan modul elektronik ini dan didampingi oleh pengembang. Jika ada hal-hal yang belum dimengerti, mahasiswa dapat bertanya secara langsung tentang hal-hal yang berkaitan dengan pengembangan produk ini. Setelah menggunakan modul elektronik ini mahasiswa diminta untuk memberi penilaian, komentar dan saran perbaikan.

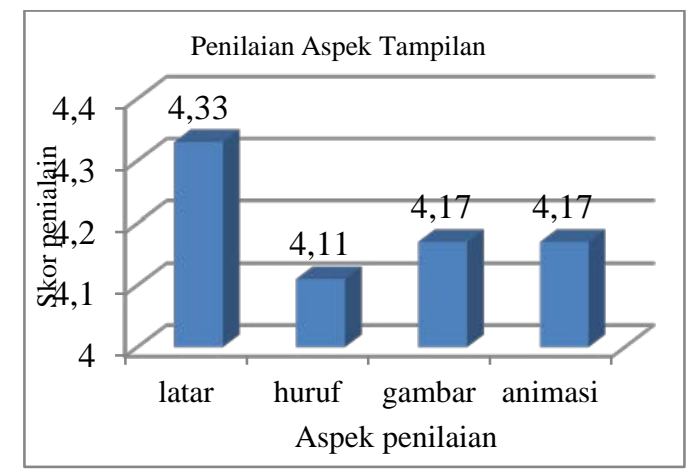

Gambar 5. Diagram perolehan penilaian uji coba satu-satu

Penilaian dilakukan dengan mengisi instrument angket yang telah disediakan oleh pengembang. Hasil penilaian yang dilakukan oleh mahasiswa dalam uji coba satu-satu akan digunakan sebagai pedoman untuk melakukan revisi tahap kedua. Skor penilaian pada uji coba satu-satu aspek tampilan didapatkan hasil data bahwa: (a) kualitas latar adalah "sangat baik" dengan rata-rata nilai "4,33”; (b) kualitas huruf "baik” dengan rata-rata nilai “4,11”; (c) kualitas gambar "sangat baik" dengan rata-rata nilai "4,17”; (d) kualitas 3D Pageflip Professional "baik" dengan rata-rata nilai "4,17”. Secara 
visual, penilaian peserta didik pada aspek isi/materi terlihat pada Gambar 5.

Dari beberapa item yang dinilai dalam aspek tampilan ini dapat disimpulkan bahwa penilaain mahasiswa tentang modul elektronik ini adalah "Baik". Jumlah penilaian yang didapat dari ketiga mahasiswa tersebut adalah 139 dengan rata-rata penilaian 4,20 kriteria "baik".

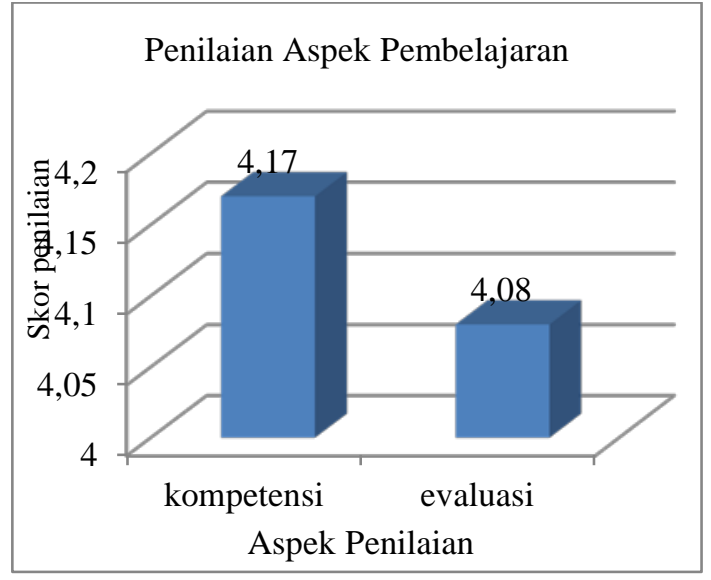

Gambar 6. Diagram perolehan aspek pembelajaran

Penilaian dalam aspek pembelajaran ini terdiri dari kualitas kompetensi dan kualitas evaluasi yang terdapat dalam produk modul elektronik ini. Data yang diperoleh dari penilaian peserta didik menunjukan bahwa: (a) kualitas kompetensi "baik" dengan rata-rata nilai “4,17”; (b) kualitas pendahuluan "baik" dengan rata-rata "4"; (c) kualitas evaluasi hasil "baik" dengan rata-rata nilai “4,08”. Secara visual, penilaian peserta didik pada aspek pembelajaran pada Gambar 6.

Dari hasil penilaian peserta didik pada aspek pembelajaran di atas, dapat disimpulakan modul elektronik yang dikembangkan mempunyai penilaian dengan kriteria "Baik" rata-rata penilaian sebesar 4,2.

Aspek isi dimaksudkan untuk mengetahui bagaimana tanggapan mahasiswa sebagai pengguna mengenai berbagai macam hal yang menyangkut isi dari produk modul elektronik ini. Data yang diperoleh dari penilaian peserta didik dari beberapa aspek isi menunjukan bahwa: (a) kualitas materi dengan rata-rata nilai "4,39 "Sangat baik"; (b) kualitas soal tes dengan ratarata nilai “3,58”. kriteria "baik”. Secara visual pada aspek isi/materi terlihat pada Gambar 7.

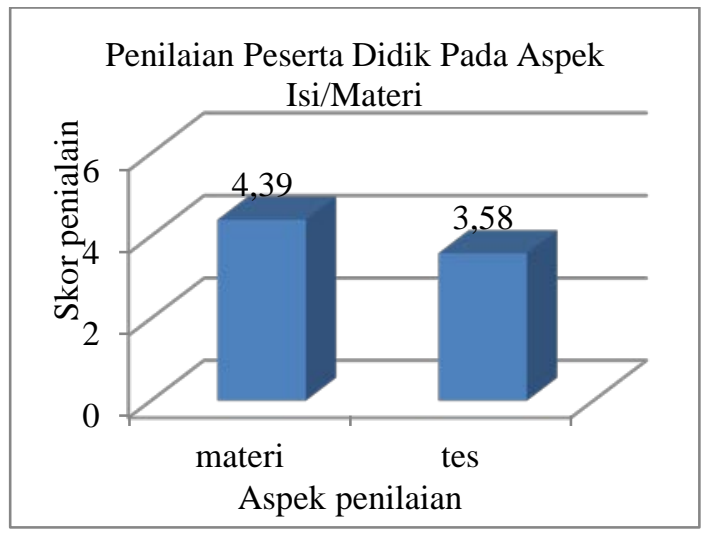

Gambar 7. Diagram perolehan uji coba satu-satu aspek isi/materi

Dari hasil penilaian peserta didik pada aspek isi di atas, dapat disimpulakan modul elektronik yang dikembangkan mempunyai penilaian dengan kriteria "Baik" dengan ratarata penilaian sebesar 4,02 .

Dari hasil uji coba satu-satu tersebut, dapat disimpulkan bahwa hasil penilaian secara keseluruhan aspek pada uji coba satu-sat menunjukan bahwa modul elektronik memiliki kriteria "baik”.

Uji Coba Kelompok Kecil. Setelah melakukan uji coba satu-satu dan melakukan revisi atau perbaikan pengembang melanjutkan dengan uji coba kelompok kecil. Responden yang menjadi subjek uji coba kelompok kecil ini berjumlah 9 orang mahasiswa.

Hasil data yang diperoleh dari penilaian uji coba kelompok kecil untuk aspek tampilan menunjukan bahwa: (a) Jumlah penilaian pada kualitas latar adalah 150 dengan rata-rata "4,17" dengan kriteria "Baik"; (b) Jumlah penilaian pada kualitas huruf adalah 120 dengan rata-rata “4,44 dengan kriteria “Sangat Baik”; (c) Jumlah penilaian pada kualitas gambar adalah 77 dengan rata-rata "4,28" dengan kriteria "Sangat Baik"; (d) Jumlah penilaian pada kualitas 3D Pageflip 
Professional adalah 76 dengan rata-rata "4,22" dengan kriteria "Sangat Baik". Secara visual, penilaian peserta didik aspek tampilan pada uji coba kelompok kecil terlihat pada Gambar 8.

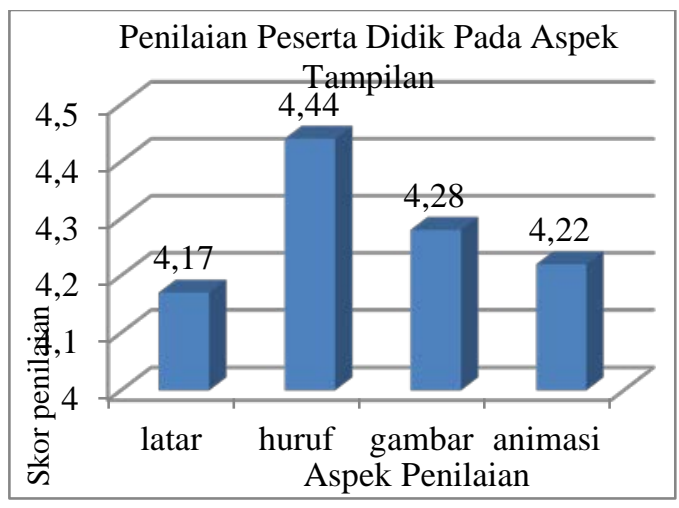

Gambar 8. Diagram penilaian aspek tampilan uji coba kelompok kecil

Dari beberapa item yang dinilai dalam aspek tampilan ini dapat disimpulkan bahwa penilaain mahasiswa pada uji coba kelompok kecil tentang modul elektronik ini adalah "Sangat Baik".

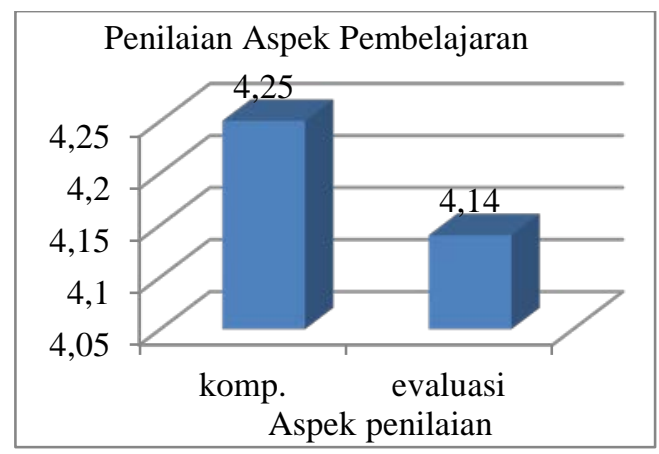

Gambar 9. Diagram batang penilaian aspek pembelajaran

Hasil data yang diperoleh dari penilaian uji coba kelompok kecil untuk aspek pembelajaran menunjukan data sebagai berikut: (a) pada kualitas kompetensi jumlah penilaian yang diperoleh sebesar 153 dengan rata-rata nilai “4,25” dengan kriteria "sangat baik"; (b) pada kualitas evaluasi jumlah penilaian pada kualitas pembelajaran ini adalah 149 dengan rata-rata nilai “4,14". Dengan kriteria "baik”. Secara visual, penilaian peserta didik pada aspek pembelajaran pada uji coba kelompok kecil terlihat pada Gambar 9.

Dari hasil penilaian peserta didik yang dilakukan dalam ujicoba kelompok kecil pada aspek pembelajaran disimpulakan modul elektronik yang dikembangkan mempunyai penilaian "Baik" rata-rata 4,22.

Data yang diperoleh dari penilaian uji coba kelompok kecil untuk aspek materi/isi menunjukan hasil sebagai berikut: (a) pada kualitas materi jumlah penilaian yang diperoleh sebesar 228 dengan rata-rata nilai "4,22" dengan kriteria "Sangat baik"; (b) pada kualitas soal tes jumlah penilaian pada kualitas isi ini adalah 142 dengan rata-rata nilai "3,94" dengan kriteria "baik". Secara visual, penilaian peserta didik pada aspek isi pada uji coba kelompok kecil terlihat pada Gambar 10.

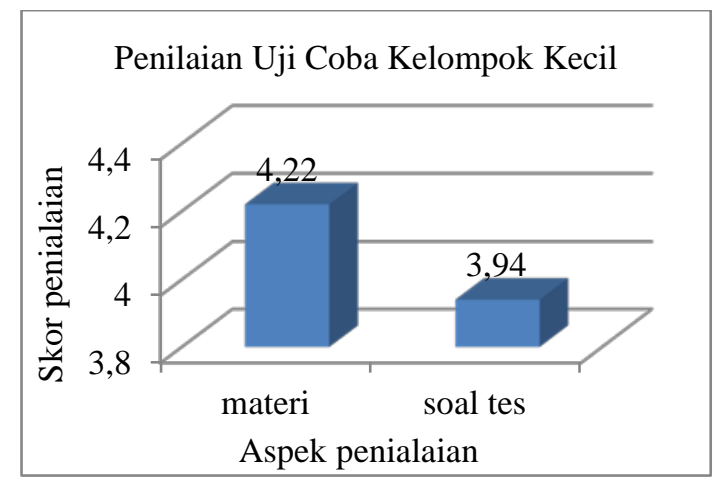

Gambar 10. Diagram penilaian aspek isi/materi uji coba kelompok kecil

Dari hasil penilaian peserta didik pada aspek isi, dapat disimpulakan jumlah keseluruhan penilaian dari keempat kriteria adalah 524 dengan rata-rata penilaian sebesar 4,16. dari penilaian ini menunjukan bahwa modul elektronik yang dikembangkan mempunyai penilaian dengan kriteria "Baik". Dari hasil analisis uji coba kelompok kecil tersebut, dapat disimpulkan bahwa kualitas modul elektronik yang dikembangkan ditinjau dari aspek tampilan, aspek pemogaman, aspek pembelajaran dan aspek isi/materi dinilai "sangat baik". 
Uji coba lapangan. Uji coba lapangan merupakan uji coba utama untuk mengukur kalayakan produk modul elektronik yang dikembangkan. Dengan uji coba lapangan ini diharapkan pengembang akan mengetahui bagian-bagian mana yang telah dianggap baik oleh mahasiswa dan bagian-bagian mana yang memerlukan perbaikan, karena pada dasarnya tujuan penelitian pengembangan ini adalah untuk menghasilkan produk Gambar Teknik yang layak digunakan untuk membantu proses pembelajaran di program studi pendidikan teknik mesin.

Uji coba lapangan dilakukan oleh 20 orang mahasiswa Program Studi Pendidikan Teknik Mesin kelas Indralaya. Hasil uji coba lapangan diperoleh dari penilaian uji coba lapangan untuk aspek tampilan menunjukan bahwa: (a) Jumlah penilaian pada kualitas latar adalah 346 dengan rata-rata "4,33" dengan kriteria "sangat Baik"; (b) Jumlah penilaian pada kualitas huruf adalah 257 dengan rata-rata “4,28” dengan kriteria "sangat Baik"; (c) Jumlah penilaian pada kualitas gambar adalah 176 dengan rata-rata “4,4” dengan kriteria "Sangat Baik"; (d) Jumlah penilaian pada kualitas 3D Pageflip Professional adalah 177 dengan rata-rata "4,43" dengan kriteria "Sangat Baik”. Secara visual hasil penilaian pengembangan modul elektronik materi Gambar Teknik untuk aspek tampilan pada uji coba kelompok kecil disampaikan dalam Gambar 11.

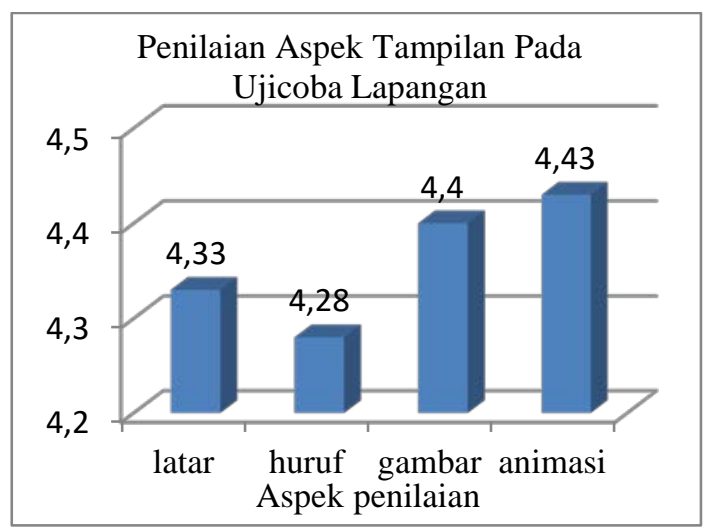

Gambar 11. Diagram batang penilaian aspek tampilan uji coba lapangan
Dari beberapa item yang dinilai dalam aspek tampilan ini adalah jumlah penilaian yang didapat dari kesembilan mahasiswa tersebut yaitu 956 dengan rata-rata penilaian “4,36”. Sehingga dapat disimpulkan bahwa penilaain mahasiswa pada uji coba kelompok kecil tentang modul elektronik ini adalah “Sangat Baik”.

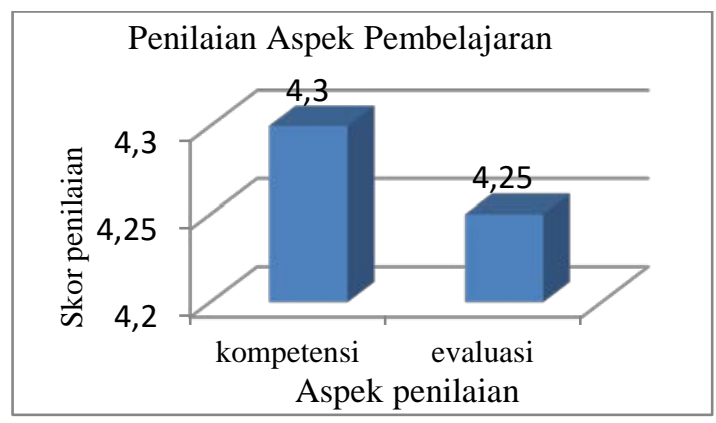

Gambar 12. Diagram penilaian aspek pembelajaran ujicoba lapangan

Berdasarkan hasil data yang diperoleh dari penilaian uji coba lapangan untuk aspek pembelajaran menunjukan data sebagai berikut: (a) pada kualitas kompetensi jumlah penilaian yang diperoleh sebesar 344 dengan rata-rata nilai “4,3" memiliki kriteria "sangat baik"; (b) pada kualitas evaluasi jumlah penilaian pada kualitas pembelajaran ini adalah 340 dengan rata-rata nilai “4,25" memiliki kriteria "sangat baik". Secara visual, penilaian peserta didik pada aspek pembelajaran pada uji coba kelompok kecil terlihat pada Gambar 12.

Dari hasil penilaian peserta didik yang dilakukan oleh 20 orang mahasiswa dalam uji coba lapangan pada aspek pembelajaran di atas dapat disimpulakan modul elektronik yang dikembangkan mempunyai penilaian "Sangat Baik".

Data yang diperoleh dari penilaian uji coba lapangan untuk aspek materi/isi menunjukan hasil sebagai berikut: (a) pada kualitas materi jumlah penilaian yang diperoleh sebesar 512 dengan rata-rata nilai " 4,2 " memiliki kriteria "Sangat Baik"; (b) pada kualitas soal tes jumlah penilaian pada kualitas isi ini adalah 335 dengan rata-rata nilai “4,19” memiliki kriteria 
"baik”. Secara visual, penilaian peserta didik pada aspek pemograman pada uji coba kelompok kecil terlihat pada Gambar 13.

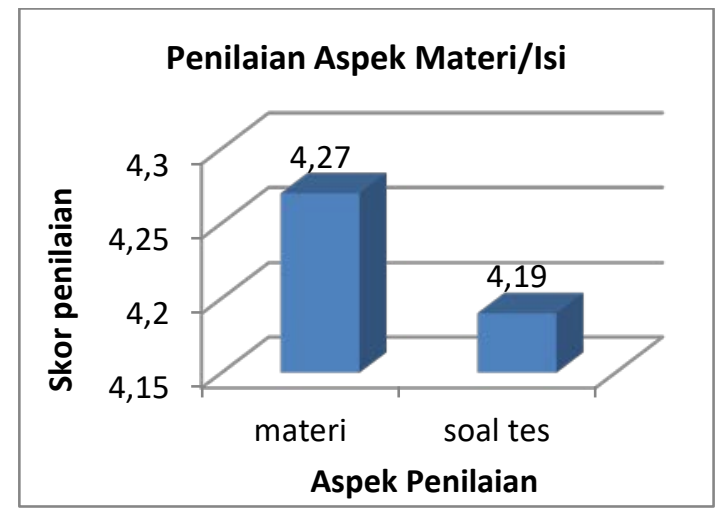

Gambar 13. Diagram penilaian aspek materi/isi uji coba lapangan

Dari hasil penilaian peserta didik pada aspek isi, dapat disimpulakan jumlah keseluruhan penilaian dari keempat kriteria adalah 847 dengan rata-rata penilaian sebesar 4,23. Dari penilaian ini menunjukan bahwa modul elektronik yang dikembangkan mempunyai penilaian dengan kriteria "Sangat baik".

Dari hasil analisis uji coba kelompok kecil tersebut, dapat disimpulkan bahwa kualitas modul elektronik yang dikembangkan ditinjau dari aspek tampilan, aspek pembelajaran, aspek isi/materi untuk uji coba kelompok dinilai Sangat Baik. Sehingga, secara keseluruhan yang dinilai dari hasil uji coba lapangan termasuk dalam kriteria sangat baik. Untuk itu produk modul elektronik pada mata kuliah Gambar Teknik dapat digunakan dan dinyatakan sebagai produk final.

\section{SIMPULAN}

Produk yang dihasilkan berupa modul elektronik berbasis 3D Pageflip Professional pada mata kuliah Gambar Teknik yang layak untuk digunakan dalam proses pembelajaran pada Program Studi Pendidikan Teknik Mesin Fakultas Keguruan dan Ilmu Pendidikan Universitas Sriwijaya. Kualitas produk modul elektronik berbasis 3D Pageflip Professional pada mata kuliah Gambar Teknik ini sangat baik. Hal ini terlihat dari hasil penilaian ahli media dan ahli materi tentang kelayakan modul elektronik ini, ditinjau dari aspek tampilan sebesar 85 rata-rata 4,3 dengan kriteria sangat baik, aspek pembelajaran sebesar 51 rata-rata 3,91 dengan kriteria baik, dan aspek materi sebesar 54 rata-rata $3 . .86$ dengan kriteria baik. Sedangkan hasil penialaian peserta didik uji lapangan pada aspek tampilan sebesar 956 ratarata 4,36 kriteria "sangat baik", pada aspek pembelajaran sebesar 684 rata-rata 4,28 dengan kriteria "sangat baik", dan pada aspek isi sebesar 847 rata-rata 4,23 kriteria "sangat baik".

Modul elektronik berbasis 3D Pageflip Professional pada mata kuliah Gambar Teknik ini efektif digunakan dalam proses pembelajaran, oleh karena itu pengembang sangat mengharapkan modul ini bisa digunakan dosen dalam proses pembelajaran mata kuliah Gambar Teknik untuk mencapai tujuan pembelajaran.

\section{DAFTAR RUJUKAN}

Hamalik, Oemar. 2007. Media Pendidikan. Bandung: Alumni.

Hamalik, O. (2009) Pendekatan baru strategi belajar mengajar berdasarkan CBSA. Jakarta: Sinar Baru Algensindo.

Irianto, A. (2008) Statistik konsep dasar dan aplikasinya. Jakarta: Kencana Prenada Media Grup.

Thiagarajan, S. Semmel, D.S \& Semmel, M. (1974). Instructional Development for Training Teachers of Exceptional Children. Indiana: Indiana University Bloomington. 